\title{
Design of Belt Conveyor for Sandblasting Material Handling System
}

\author{
Rudi Suhradi Rachmat, ${ }^{1, a}$, Liwiryon Sudarso ${ }^{2, b}$ \\ 1,2Mechanical Engineering Department, President University, Indonesia. \\ JI. Ki Hajar Dewantara, Jababeka Education Center, Cikarang, Bekasi \\ arudi.sr@president.ac.id, bliwiryon_sudarso@yahoo.co.id
}

\begin{abstract}
Abstrak.
Screw conveyor adalah peralatan transfer bahan yang sering digunakan di berbagai jenis industri. Namun, sekrup konveyor juga memiliki beberapa kelemahan jika digunakan di ruang peledakan berfungsi untuk mengangkut pasir baja yang merupakan bahan utama dalam proses peledakan. Konveyor sekrup ini sering mengalami kerusakan pada blok bantal karena dimasukkannya grit baja. Berdasarkan kondisi lapangan, kapasitas angkut konveyor sekrup dianggap tidak efisien karena sebagian grit baja tertinggal di celah antara sekrup dan pelat baja melengkung dan tidak dapat diangkut dengan konveyor sekrup. Untuk mengatasi masalah tersebut, konveyor sabuk dipilih untuk mengganti konveyor sekrup. Metode yang digunakan dalam tugas akhir ini, pertama adalah mengidentifikasi masalah conveyor sekrup yang ada dan mengamati data conveyor sekrup. Kedua, dengan menggunakan data screw conveyor, penulis membuat desain conveyor belt sebagai pengganti screw conveyor yang ada. Hasilnya, desain konveyor sabuk telah dibuat dengan kapasitas terhitung 236,81 ton / jam, yang lebih besar dari konveyor sekrup yang ada. dan dirancang agar tidak mudah rusak karena dimasukkannya grit baja seperti yang terjadi pada conveyor sekrup.
\end{abstract}

Kata kunci. Screw Conveyor, Belt Conveyor, Grit Baja, Ruang Peledakan, Bantal Blok, Kapasitas, Desain

\begin{abstract}
.
Screw conveyor is a material transfer equipment that is often used in various types of industries. However, the screw conveyor also has some disadvantages if it used in the blasting room serves to transport the steel grit which is the main material in the blasting process. This screw conveyor often suffers damage to the pillow block due to the inclusion of steel grit. Based on field conditions, the screw conveyor transport capacity is considered inefficient because some of the steel grit left in the gap between the screw and the curved steel plate and not get transported by screw conveyor. In order to overcome the problems, a belt conveyor is chosen to replace the screw conveyor. The method used in this final project, firstly is identifying the problem of the existing screw conveyor and observing the screw conveyor data. Secondly, by using the screw conveyor data, author make a design of belt conveyor as the replacement of existing screw conveyor. As a result, the belt conveyor design has been created with calculated capacity of 236.81 tons/hour, which is greater than the existing screw conveyor. and is designed not to be easily damaged due to the inclusion of steel grit as it happened in the screw conveyor.
\end{abstract}

Keywords. Screw Conveyor, Belt Conveyor, Steel Grit, Blasting Room, Pillow Block, Capacity, Design

\section{Introduction}

Screw conveyor is one of the restoration systems that is often used for medium-heavy abrasive materials [1]. In practice, a screw conveyor is used in the process of steel grit handling system in PT. United Tractors Pandu Engineering [2]. However, the use of screw conveyors for steel grit handling system at PT. United Tractor Engineering, almost routinely experience damage to the pillow block bearing and screw conveyor transport capacity is considered inefficient because some of the steel grit 
left in the gap between the screw and the curved steel plate and not get transported by screw conveyor [2].

For the process of transporting an object or material, the belt conveyor is one of the equipments that is often used [3]. Zhao (2011), stated that belt conveyors are often chosen as a sustainable transportation medium where belt conveyor has high efficiency, large haulage, simpler construction, and easier maintenance. The use of the belt conveyor itself also covers several fields in the industry where even though it has the same use of transporting objects or materials, the models and materials used in the belt conveyor will differ according to needs. Based on the problem that mentioned above, the company want to replace the existing screw conveyor with belt conveyor. Therefore, the author is interested to make a new design of the belt conveyor system based on the data taken from existing screw conveyor system.

\section{Methodology}

This chapter will clearly discuss the methods used by the author is conducting research and design for the design of belt conveyors that will be used as material handling systems in sandblasting rooms. In making it easier for readers to know the overall method used in this paper, Figure 1 is the flow chart that is the author's reference in conducting research and Figure 2 shows the process to do the detailed design process.

Detailed Design Process Flow Chart

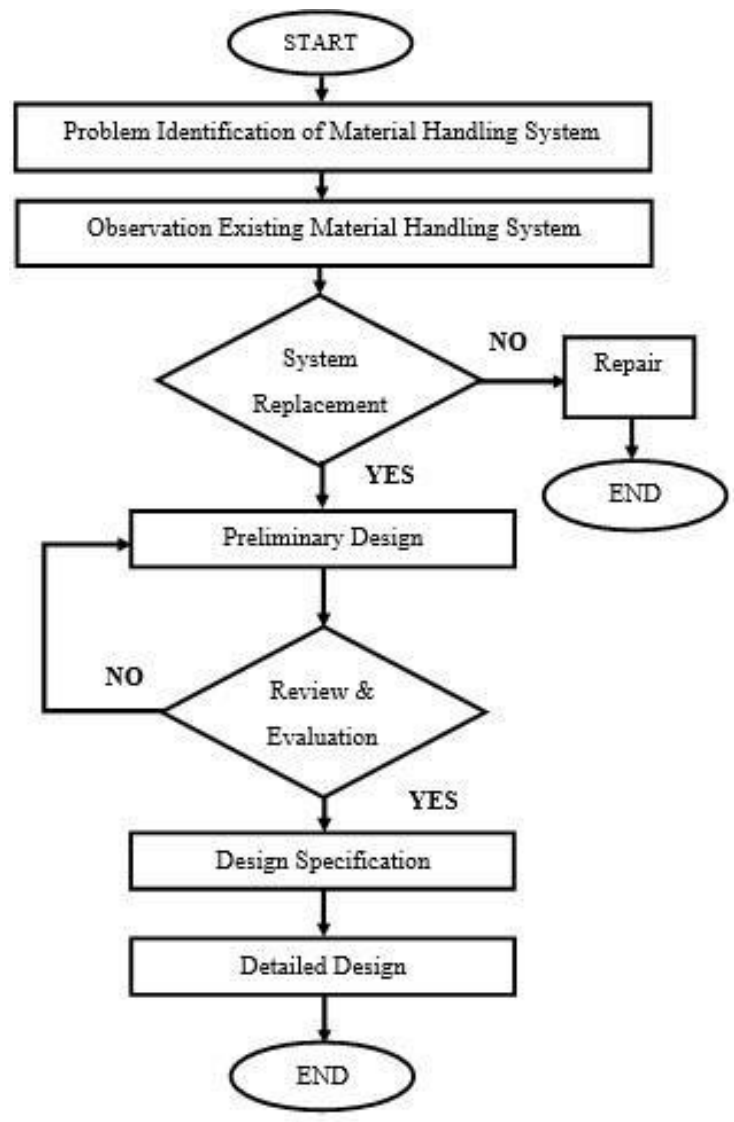

Figure 1. Research Methodology

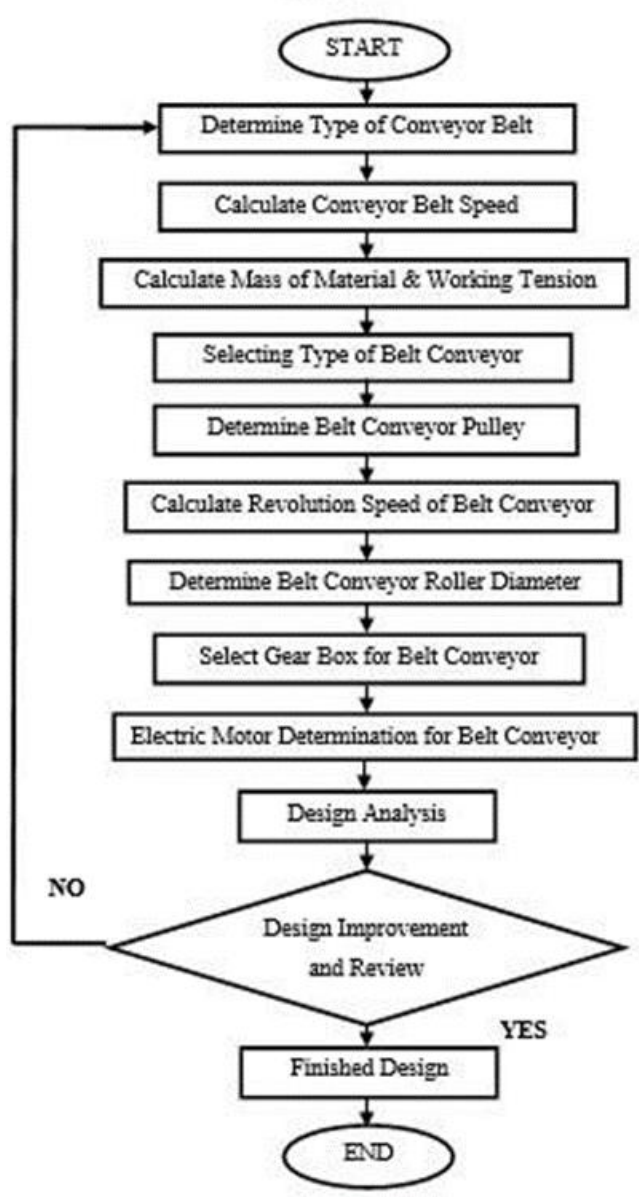

Figure 2. Detailed Design Flow Chart

\section{Problem Identification of Material Handling System}

The sandblasting process is needed to eliminate corrosion, roughing up a surface material that will be used in a product. In practice, sandblasting uses iron sand or commonly referred to as steel grit. Some types of steel grit can basically be used again after a sandblasting process. Before a popular handling 
system is used, operators usually spend their time collecting steel grits on the floor of the sandblasting room and moving them manually to the reservoir for reuse. Knowing that this was not efficient, PT. United Tractors Pandu Engineering decided to indeed be a screw conveyor-based handling system to move the used steel grit to the reservoir, where the screw conveyor is one of the restoration systems that is often used for medium-heavy abrasive materials [1]. However, after 3 years of use, several problems began to appear.

\section{Observation of Existing Material Handling System}

In practice, a screw conveyor is used in the process of steel grit restoration in PT. United Tractors Pandu Engineering [2]. However, in practice the use of screw conveyors for steel grit restoration systems at PT. United Tractor Engineering, screw conveyors almost routinely experience damage to the pillow block bearing and restoration efficiency that does not meet standards. This certainly causes huge losses because it disrupts production activities. In response to this, PT United Tractors Pandu Engineering intends to replace the screw conveyor and use the belt conveyor as a material handling system because the belt conveyor is believed to be more effective and easier in terms of maintenance. Therefore, in this writing, the author will calculate and design a suitable belt conveyor design as a material handling system in the sandblasting room. The table below shows the data of the screw conveyor that will be replaced later'.

Table 1. Screw Conveyor Data Table

\begin{tabular}{l|l|l}
\hline No & \multicolumn{1}{|c}{ Data } & \multicolumn{1}{c}{ Specification } \\
\hline 1 & Screw Conveyor & $12,000(\mathrm{~L}) \times 300(\varnothing) \mathrm{mm}$ \\
2 & Shaft & As ST 41 ø 5" + Pipe SCH 80, $5 ”$ \\
3 & Screw Pitch & $130 \mathrm{~mm}$ \\
4 & Screw Rotating Speed & $20 \mathrm{rpm}$ \\
5 & Motor Power & $3.7 \mathrm{KW} / 380 \mathrm{~V} / 3$ Phase /4 Pole \\
6 & Bearing Unit & SKF, UCFS 313 $\varnothing 65 \mathrm{~mm}$ \\
7 & Screw Conveyor Capacity & 3.4785 ton/hour \\
\hline
\end{tabular}

\section{System Replacement}

Looking at the condition of the screw conveyor as the existing handling system in the sandblasting room which is often damaged and disrupts the course of production, PT. United Tractors Pandu Engineering decided to replace the handling system by using another conveyor system. We know that there are several types of conveyor systems which have their own designs and uses, as we can see in Table 2 which shows several types of conveyors and their uses.

Based on Table 2, it can be concluded that actually the screw conveyor is not appropriate to be used to transport material in the form of steel grit because of its abrasive character and its very small size. Based on field conditions, congestion due to screw rotation disorders caused by the inclusion of steel grit in the pillow block usually causes damage to the screw and results in the need for screw replacement [1]. Not only that, if there is an overload due to heavy screw rotation, it will cause damage to the motor. Therefore, it was decided to change the handling system from the screw conveyor to the conveyor belt based on the considerations in Table 2 .

\section{Preliminary Design}

In designing the belt conveyor design at this writing, the author requires the design of the design through two stages, which are preliminary design and detailed design. What is done by the author in the preliminary design is drawing a simple design of a belt conveyor by using the reference dimensions of the screw conveyor that has been installed and roughly determining the design of the belt conveyor to be used without making significant calculations. On top of that, in the preliminary 
design author only focuses on a few components of the belt conveyor, which does not include motors, gearboxes and accessories. The author uses CATIA V5 software to design the conveyor belt in this final project. Here is the design created by the author at the preliminary design stage;

Table 2. Screw and Belt Conveyor Comparison

\begin{tabular}{|c|c|c|c|}
\hline Conveyor Type & Function & Advantages & Disadvantages \\
\hline Belt Conveyor [4] & $\begin{array}{l}\text { Transport in the form of } \\
\text { units or bulk with a large } \\
\text { enough capacity using a } \\
\text { media belt and can be } \\
\text { horizontal or sloped at } \\
\text { the desired angle }\end{array}$ & $\begin{array}{l}\text { a. Easier to maintain belt } \\
\text { because it is a single unit } \\
\text { and not a small component } \\
\text { b. Easy installation and repair } \\
\text { c. If there is damage to the } \\
\text { belt, it will not damage } \\
\text { other components } \\
\text { (especially the motor) } \\
\text { d. Can be used to transport } \\
\text { abrasive materials }\end{array}$ & $\begin{array}{l}\text { a. If the belt is torn, the } \\
\text { strength of the belt will } \\
\text { decrease and must be } \\
\text { replaced immediately. } \\
\text { b. Connection of the two ends } \\
\text { of the belt during } \\
\text { installation must be done by } \\
\text { expert. } \\
\text { c. Conveyor belts must be } \\
\text { installed in a straight } \\
\text { position and cannot turn } \\
\text { through the room, in } \\
\text { contrast to the module } \\
\text { system. } \\
\text { d. The elevation angle is } \\
\text { limited because if it is too } \\
\text { large then the material } \\
\text { transported can degenerate. }\end{array}$ \\
\hline IEw comveyou [J] & $\begin{array}{l}\text { Transport semi- } \text { solid } \\
\text { and non- coherent } \\
\text { material by pushing in a } \\
\text { spiral around the shaft }\end{array}$ & $\begin{array}{l}\text { a. Can be used as a mixing } \\
\text { material other than media to } \\
\text { transport material } \\
\text { b. Prices of new products are } \\
\text { affordable }\end{array}$ & $\begin{array}{l}\text { a. Not suitable for abrasive } \\
\text { material } \\
\text { b. Friction material on the } \\
\text { screw that causes high } \\
\text { power consumption } \\
\text { c. Overload can cause } \\
\text { congestion, damage the } \\
\text { shaft and gear and the } \\
\text { motor. } \\
\text { d. Incorrect installation can } \\
\text { cause fatal damage to the } \\
\text { screw conveyor }\end{array}$ \\
\hline
\end{tabular}

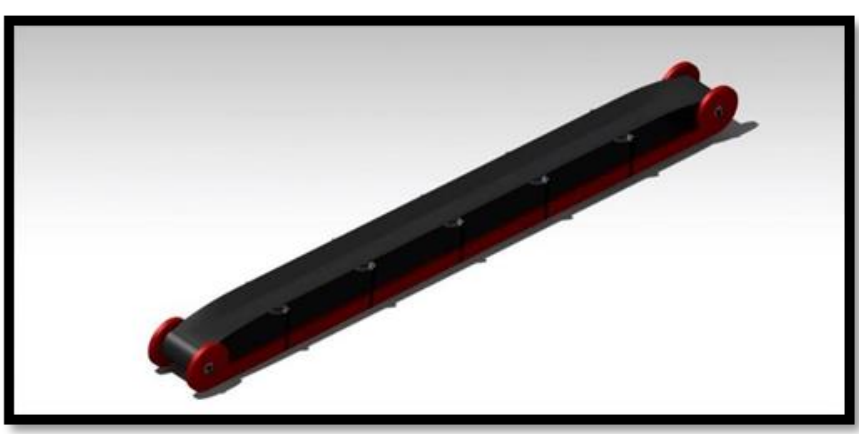

Figure 3. Full Assembly of Belt Conveyor

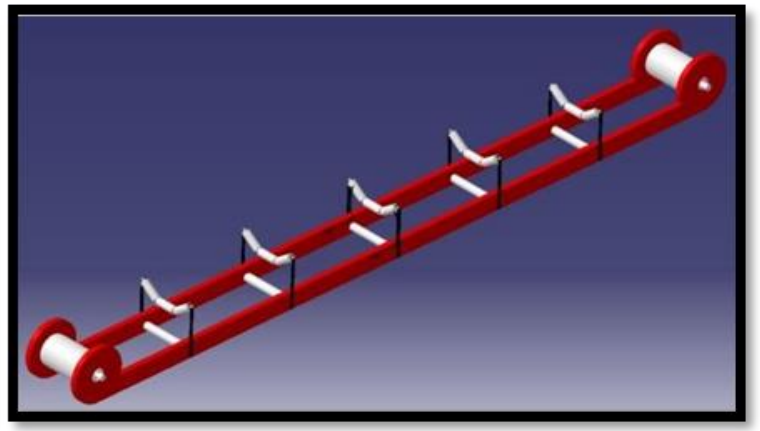

Figure 4. Assembly without Belt

Based on the literature that has been studied, the author decided to design a belt conveyor using a troughing idler roller with a troughing angle of 350 which is often used in the installation of longdistance belt conveyor and hauling abrasive material. On top of that, the author believes that the design with 3 roll idlers is more effective in transporting steel grit used because steel grit will gather in the middle of the belt and not scattered everywhere where the shape of the belt cross-sectional area such as trapezoidal so that it resists the movement of steel grit, compared with a flat belt conveyor. The figure below is the design and sketch illustration of the conveyor's idler roller belt which shows the shape of the idler with a troughing angle of $35^{\circ}$. 

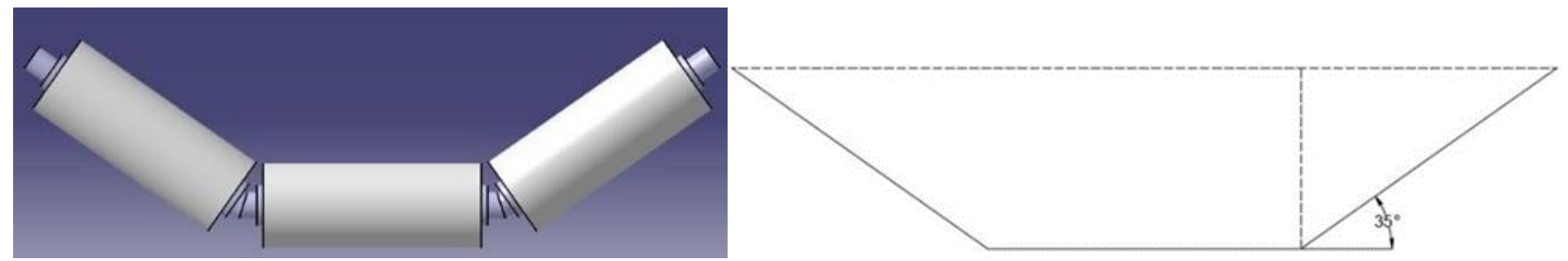

Figure 5. Sketch Illustration and 3D Design for Roller Idlers

\section{Design Specification}

Before proceeding to the detailed design process stage, the author needs to set a design specification to indicate a clearer direction for the design of the conveyor belt to be made. Next is Table 3 which shows the design specifications that will be made by the author;

Table 3. Design Specification Table

\begin{tabular}{l|c|c}
\hline \multicolumn{1}{c|}{ Specification } & Unit / Item & Value / Size \\
\hline Capacity & Ton/hour & 3.4785 \\
Volume Flow Rate & $\mathrm{m}^{3} / \mathrm{s}$ & $1.15 \times 10^{-4}$ \\
Transporting Distance & $\mathrm{m}$ & 12 \\
Transported Material & Steel grit & $1 \mathrm{~mm} \mathrm{Diameter}$ \\
Inclination Angle & Degree & 0 \\
\hline
\end{tabular}

\section{Detailed Design Process}

After passing the Preliminary Design stage, the author has begun to have a picture to provide details on each component in the belt conveyor design. These details come from the screw conveyor reference, the basic belt conveyor calculation formula and the standard of the belt conveyor itself. Some reference sizes of parts that will be used on the belt conveyor are from handbooks, catalog books and journals from someone who has ever discussed the design of belt conveyor designs.

\section{A. Conveyor Belt Determination}

Determination of the type of belt that will be used in the design of the conveyor belt will be an important parameter in determining the size of the design. This will be proven with the data and tables that become the author's preference. In determining the type of belt used, the author needs to consider the characteristics and specifications of the belt. In this conveyor belt design, the belt used must be able to carry abrasive materials, high wear resistance, maximum recommended through angle for three roller idlers $45 o$ and not susceptible to moisture and microorganisms. One of the belts that fulfill all of these qualifications is the RO-PLY rubber conveyor belts produced by Roulounds Fabriker [6].

\section{B. Conveyor Belt Speed Calculation}

Based on the literature study conducted by the author in the previous chapter, the author found that to determine the dimensions of the conveyor belt design is to determine the linear velocity of the conveyor belt itself. In the Fenner Dunlop handbook, there are several formulas that can be used to find the linear velocity of the conveyor belt [7]. It should be noted that the design to be created is a design using 3 equal roller idlers, so the formula used is a special formula for that design.

$$
C=3.6 \times A \times \rho \times C_{f} \times v
$$

Given, $\mathrm{C}=$ Capacity (tons per hour), $\mathrm{A}=$ Conveyor's belt cross sectional area $\left(\mathrm{m}^{\wedge} 2\right), \rho=$ Material density $\left(\mathrm{kg} / \mathrm{m}^{\wedge} 3\right), \mathrm{C}_{\mathrm{f}}=$ Capacity factor, $\mathrm{v}=$ Belt speed $(\mathrm{m} / \mathrm{s})$.

$$
A=\frac{\left(L+\frac{x}{3}\right) \cdot h}{2}
$$


Where, $\mathrm{A}=$ Cross-sectional area, $\mathrm{L}=$ Length of trapezoid's base $(\mathrm{X} / 3+2 \mathrm{z}), \mathrm{X}=$ Conveyor belt length, $\mathrm{h}=$ Height of trapezoid $(\mathrm{X} / 3 \mathrm{Sin} 35 o)$

\section{Mass of Material \& Working Tension Calculation}

In the previous discussion, table 9 shows some numbers that show the maximum working tension for the RO-PLY rubber belt according to its type. Before the author can determine the type of RO-PLY rubber belt to be used, the author needs to calculate the mass of material per meter loaded on the belt conveyor with a formula derived from the article entitled Design of Material Handling Equipment [8];

$\mathrm{M}_{\mathrm{m}}=\frac{C}{3.6 \times V}$,

$\mathrm{M}_{\mathrm{m}}=\frac{3.4785 \mathrm{t} / \mathrm{h}}{3.6 \times 4 \times 10^{-3} \mathrm{~m} / \mathrm{s}}=241.5625 \mathrm{~kg} / \mathrm{m}$

Working Tension $=241.5625 \mathrm{~kg} / \mathrm{m} \times 9.81 \mathrm{~m} / \mathrm{s}^{2}=2367.3 \mathrm{~N} / \mathrm{m}$

When calculating a design, the author needs to consider the safety factor. The type of belt used by the author is the type of fabric reinforced rubber belt, given that the conveyor belt experiences a dynamic load or live load, the author can use the value 8 for safety factors as in Machine Design book by R.S Khurumi [9]. However, the type of belt used is fabric reinforced rubber belts where the normal safety factor of 8 . Therefore, the author multiplies between the safety factor and the working tension becomes $8 \times 2367.3 \mathrm{~N}=18.94 \mathrm{kN} / \mathrm{m}$.

\section{Conveyor Belt Type Selection}

To determine the right type, the author has found the number of total working tension in the mass of material calculation, which is $18.94 \mathrm{kN} / \mathrm{m}$. If we take look at table on Roulound Fabriker, we know that the lowest type of belt (200/2) can still be used because it has a maximum working tension of 20 $\mathrm{N} / \mathrm{mm}$ or equal to $20 \mathrm{kN} / \mathrm{m}$. If illustrated in the illustration, it will be;

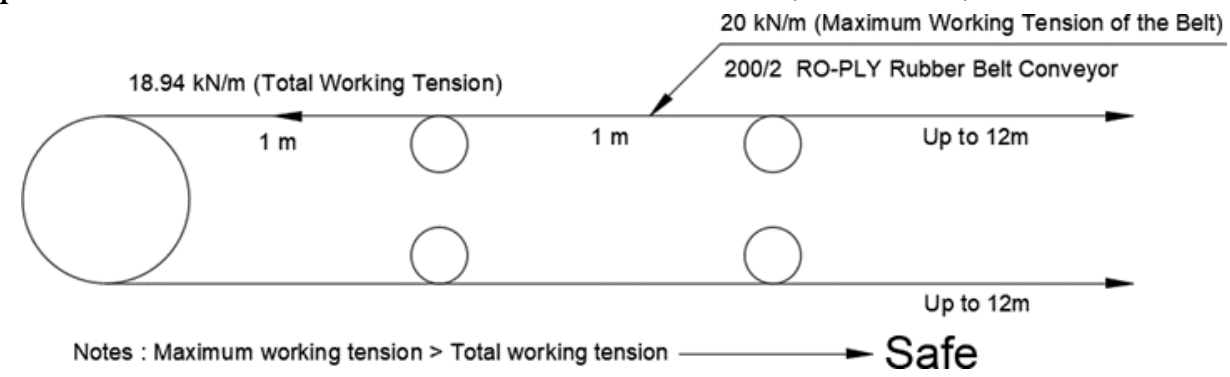

Figure 6. Working Tension on Belt Conveyor Illustration

\section{E. Belt Conveyor Pulley Determination}

In the standard conveyor belt design, there are 2 pulleys which are drive pulleys and return pulleys [4]. To determine the size of the pulley, the author uses the standard from C. KIT which shows the minimum required pulley diameter according to the type of belt and rated tension acting on the conveyor belt. For that, it is necessary to first calculate the rated tension based on the total working tension and the maximum working tension acting on the belt;

Rated tension $=\frac{\text { Total working tension }}{\text { Maximum working tension }} \times 100 \%$

Rated tension $=\frac{18.94 \mathrm{kN} / \mathrm{m}}{20 \mathrm{kN} / \mathrm{m}} \times 100 \%=94.7 \%$

To determine the minimum pulley diameter the author needs to look at 3 main parameters, namely the number of plies rated tension and type of belt used. Previously the author had calculated the rated tension where the number was close to $100 \%$. For a number of plies, the selected rubber belt conveyor uses 2 plies and type 200 and the minimum diameter required for this design is $350 \mathrm{~mm}$ [10]. 


\section{E. Revolution Speed of Belt Conveyor Calculation}

The main driving force of the conveyor belt is to use an AC motor that is connected to the gearbox with the aim of achieving a number of revolutions per minute (rpm) according to the needs of the conveyor belt design. Therefore, the author needs to first calculate the rpm that works on the conveyor belt pulley using the formula from the reference [7]. The following is the calculation of rpm that works on the conveyor pulley belt;

$$
\begin{aligned}
& \mathrm{N}=\frac{V \times 1000 \times 60}{D \times \pi} \\
& \mathrm{N}=\frac{3.76 \times 10^{-3} \frac{\mathrm{m}}{\mathrm{s}} \times 1000 \times 60}{350 \mathrm{~m} \times 3.14}=0.205 \mathrm{rpm}
\end{aligned}
$$

\section{G.Gearbox Selection for Belt Conveyor}

After knowing the rpm needed in the design of the conveyor belt with a capacity of 3.4875 tons/hour, the author needs to check the availability of gearboxes on the market. In a provider handbook called CHIARAVALLI Group, it shows that the largest ratio for products they have is 100:1 with the lowest rpm of $14 \mathrm{rpm}$ if using motor with $1400 \mathrm{rpm}$. In the previous calculation, it was known that the designed conveyor belt pulley only needed a rotation of $0.205 \mathrm{rpm}$, where the numbers did not find the pair of motors and gearboxes on the market according to the design to be made. Therefore, the author will recalculate using the number $14 \mathrm{rpm}$ in the next chapter to adjust the speed and capacity of the conveyor belt to be designed.

\section{H. Belt Conveyor Roller Diameter Determination}

One of the important parts of belt conveyor design is a roller. The roller has a role as a support for the belt conveyor so that the tension is maintained and avoid deflection that occurs due to the load placed on the conveyor belt or the load of the belt itself [7]. However, in determining the diameter of the roller does not necessarily determine without any parameters, so the author uses the roller with $89 \mathrm{~mm}$ from the Transroll Catalog [11].

\section{Result and Discussion}

It has been discussed previously that the author cannot use the belt conveyor data that has been obtained because the rpm that works on the belt conveyor pulley is too small and the maximum ratio for the gearbox only reaches 100: 1 if applying screw conveyor capacity to the conveyor belt. Table 4 below shows the data before and after the recalculation process.

Table 4. Belt Conveyor Design Data

\begin{tabular}{|l|c|c|}
\hline \multicolumn{1}{|c|}{ Description } & First Calculation Data & $\begin{array}{c}\text { Data Obtained from } \\
\text { Recalculation }\end{array}$ \\
\hline RO-PLY Rubber Belt Conveyor & Belt Type 200/2 & RO-PLY 250/2 \\
Belt Width & $650 \mathrm{~mm}$ & $650 \mathrm{~mm}$ \\
Belt Speed & $4 \mathrm{~mm} / \mathrm{s}$ & $0.256 \mathrm{~m} / \mathrm{s}$ \\
Total Working Tension & $18.94 \mathrm{kN} / \mathrm{m}$ & $20.166 \mathrm{kN} / \mathrm{m}$ \\
Belt Conveyor Pulley Diameter & $350 \mathrm{~mm}$ & $350 \mathrm{~mm}$ \\
Belt Conveyor Roller Diameter & $89 \mathrm{~mm}$ & $89 \mathrm{~mm}$ \\
Gearbox Reducer Ratio & --- & $100: 1$ \\
Rpm Working on Pulley & $0.205 \mathrm{rpm}$ & $14 \mathrm{rpm}$ \\
Belt Conveyor Capacity & $3.4785 \mathrm{t} / \mathrm{h}$ & $236.81 \mathrm{t} / \mathrm{h}$ \\
Rated Tension on Belt & $100 \%$ & $80 \%$ \\
\hline
\end{tabular}




\section{Electric Motor Determination}

Before determining the power of the motor used, the author needs to determine the power needed to move the conveyor belt first using the following formula;

$$
\mathrm{Hp}=\frac{\operatorname{Te} \times \mathrm{V}}{3300}
$$

Given, $\mathrm{Hp}=$ Belt power (Horsepower), Te = Effective belt tension (lbs), V = Belt speed (feet per minute).

$$
\text { Te }(\text { Effective belt tension })=\mathrm{Tc}+\mathrm{Tl}
$$

Where, $\mathrm{Tc}=\mathrm{F} 1 \times \mathrm{L} \times \mathrm{Cw}, \mathrm{Tc}=$ Tension required to move empty belt $(\mathrm{lbs}), \mathrm{F} 1=$ Normal friction factor for average condition to move empty belt (0.035), $\mathrm{L}=$ Belt length, $\mathrm{Cw}=$ Weight of conveyor belt component (lb), $\mathrm{Tl}=\mathrm{F} 2 \times \mathrm{L} \times \mathrm{Mw}, \mathrm{Tl}=$ Tension required to move load horizontally, $\mathrm{F} 2=$ Normal friction factor to move load horizontally (0.04), $\mathrm{L}=$ Belt legth (ft), $\mathrm{Mw}=$ Material weight $(\mathrm{lb} / \mathrm{ft})$.

$$
\begin{aligned}
& \mathrm{Hp}=\frac{\text { Te } x V}{3300} \\
& \mathrm{Hp}=\frac{747.75 \text { lbs } x 50.4 \mathrm{fpm}}{3300}=11.42 \mathrm{Hp} \\
& \text { When } 1 \mathrm{Hp}=0.7355 \mathrm{~kW} \rightarrow 11.42 \mathrm{Hp}=8.39 \mathrm{~kW}
\end{aligned}
$$

\section{Design Analysis}

The design that was created by the author requires testing the structural resistance on several important parts of the conveyor belt which will take the burden when transporting steel grit. The following are the tests conducted by the author using finite element analysis in CATIA V5 software because the structures or forms of design that are quite complex to be solved manually. To achieve the level of precision of $95 \%$, the author uses the Global Adaptivity feature where CATIA will automatically generate the mesh number until it reached the targeted precision. Here is a figure before and after using Global Adaptivity feature;

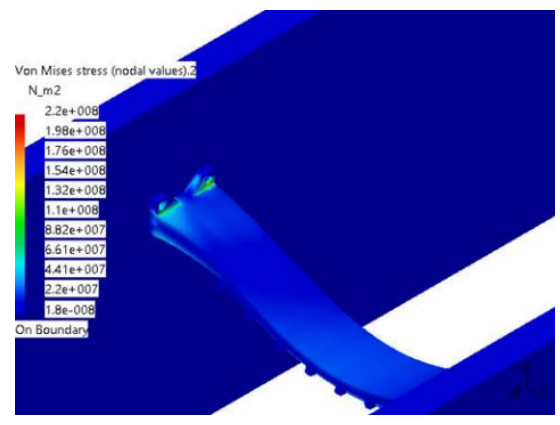

Figure 7. Von Misses Stress on Roller Idler Base

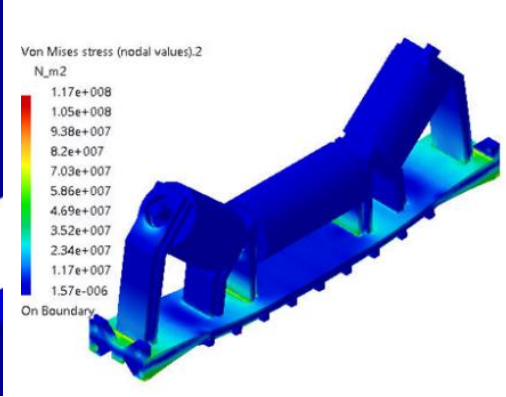

Figure 8. Von Misses Stress on Roller Idler Supporting Part

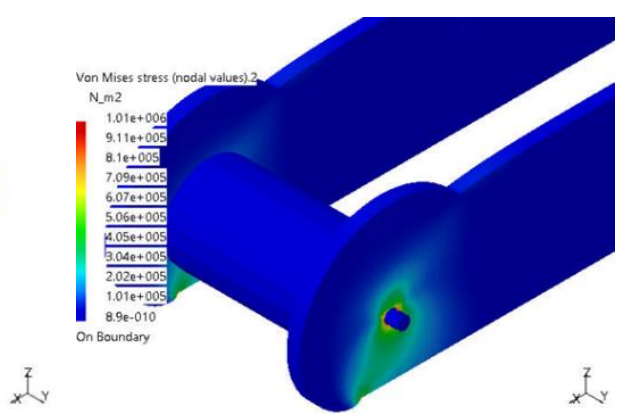

Figure 9. Von Misses Stress on Belt Conveyor Pulley

\section{Accessory Design}

The design of the finished conveyor belt, which is the result of calculations and analysis conducted by the author is basically sufficient to be operated with a specified capacity. However, the author realizes that existing designs require additional accessories that function so that the design of the conveyor belt meets the standards for carrying steel gears and is placed in a blasting room. It should be noted that the addition of accessories does not change the design that has been set in the previous discussion. 


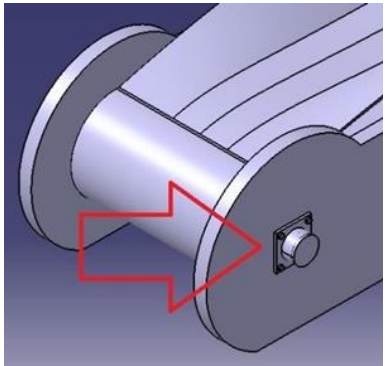

Figure 10. Pulley's Shaft and Nut Cover Figure
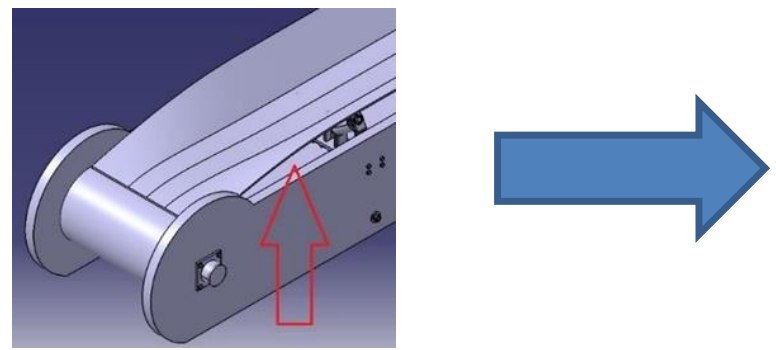

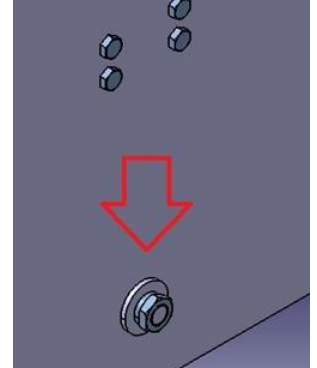

Figure 11. Bottom Roller Shaft Bearing Cover

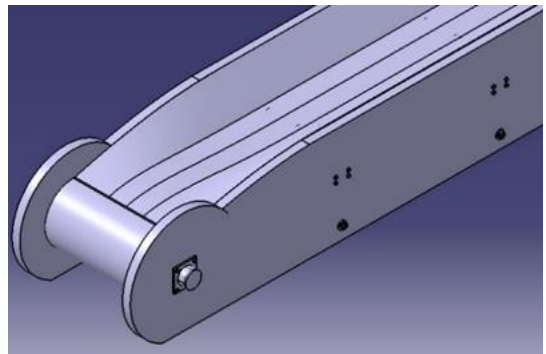

Figure 12. Steel Plate Cover for Space Between Belt Conveyor Frame and Belt
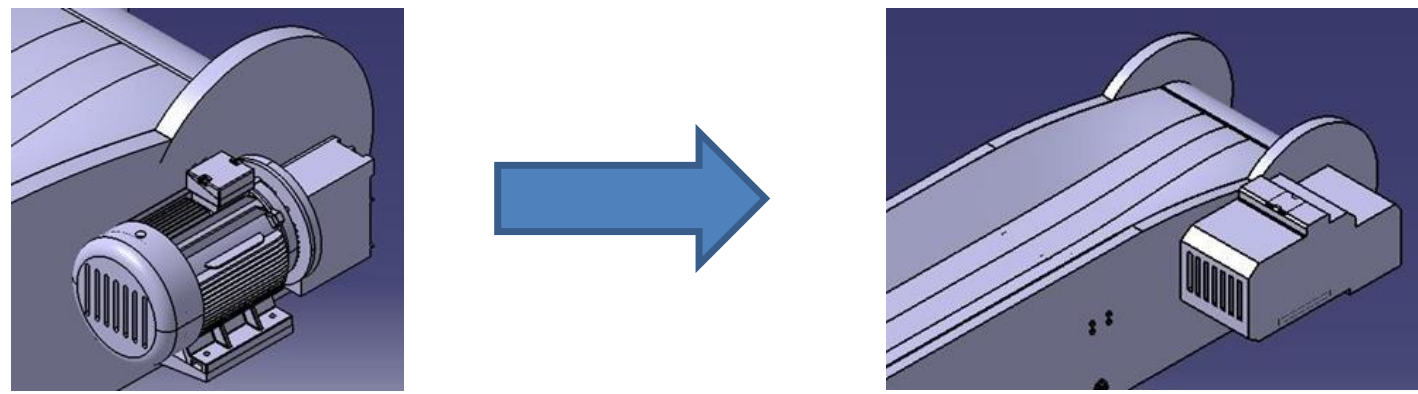

Figure 13. Motor and Gearbox Cover

\section{Conclusion}

In supporting operational activities in the sandblasting process at PT. United Tractors Pandu Engineering which often experiences obstacles caused by pillow block bearing damage of the screw conveyor and lack of efficiency in the transport of steel grit, therefore the author make a design of belt conveyor to replace the screw conveyor as a more efficient material handling system and prevent the occurrence of existing problems. In terms of capacity, the capacity of the conveyor belt is far greater than the screw conveyor, which is $236.81 \mathrm{ton} / \mathrm{h}$, where the screw conveyor only has a capacity of $3.4785 \mathrm{ton} / \mathrm{h}$.

To prevent the entry of steel grit into the components of the conveyor belt, the author has improved the design by giving cover to the gap of each part of the belt conveyor which causes the steel grit to enter and damage to the belt conveyor system. With belt speeds reaching $0.256 \mathrm{~m} / \mathrm{s}$, it enables the steel grit that has been used to return to the blasting pot from end to end of the conveyor belt for 47 seconds, which is 6 times faster than the screw conveyor which takes 279 seconds. Based on calculations in Chapter 3 and discussion in Chapter 4, final data is obtained which is the main data used in designing the belt conveyor for sandblasting material handling systems. The calculation and design of belt conveyors are in accordance with international standards and product catalogs available in the market. Table 5-8 below shows the relevant data;

Table 5. Conveyor Belt Data

\begin{tabular}{c|c}
\hline Description & Specification \\
\hline Belt Conveyor Capacity & $236.81 \mathrm{t} / \mathrm{h}^{*}$ \\
Conveyor Belt Total Length & $25100 \mathrm{~mm} *$ \\
Conveyor Belt Width & $650 \mathrm{~mm}$ \\
Belt Conveyor Type & RO-PLY $250 / 2$
\end{tabular}




\begin{tabular}{c|c} 
Belt Conveyor Speed & $0.256 \mathrm{~m} / \mathrm{s}^{*}$ \\
Total Working Tension on Conveyor Belt & $20.166 \mathrm{kN} / \mathrm{m}^{*}$ \\
Rated Tension on Conveyor Belt & $80 \% \%^{*}$ \\
Conveyor Belt Thickness & $6.6 \mathrm{~mm}$ \\
\hline \multicolumn{2}{c}{ Table 6. Belt Conveyor Pulley Data } \\
\hline Description & Specification \\
\hline Belt Conveyor Pulley Diameter & $350 \mathrm{~mm}$ \\
Belt Conveyor Pulley Length & $650 \mathrm{~mm}$ \\
Belt Conveyor Pulley Type & Flat \\
Belt Conveyor Pulley Material & Steel with $7860 \mathrm{Kg} / \mathrm{m}^{3}$ Density \\
Rotation per Minute Working on Pulley & $14 \mathrm{rpm}$ \\
Belt Conveyor Pulley Shaft Diameter & $50 \mathrm{~mm}$ \\
\hline
\end{tabular}

Table 7. Belt Conveyor Roller Idler Data

\begin{tabular}{c|c}
\hline Description & Specification \\
\hline Center and Side Roller Idler Diameter & $89 \mathrm{~mm}$ \\
Center Roller Idler Length & $186 \mathrm{~mm}$ \\
Side Roller Idler Length & $123 \mathrm{~mm}$ \\
Roller Idlers Type & $650 \mathrm{~mm}$ \\
Supporting Return Belt Roller Idler Length & $89 \mathrm{~mm}$ \\
Supporting Return Belt Roller Idler Diameter & Flat Roller idler with $35^{\circ}$ troughing angle \\
Belt Conveyor Roller Idler Materials & $20 \mathrm{~mm}$ \\
Belt Conveyor Roller Idler Shaft Diameter & \\
\hline
\end{tabular}

Table 8. Belt Conveyor Motor and Gearbox Data

\begin{tabular}{c|c}
\hline Description & Specification \\
\hline Belt Conveyor Gearbox Reducer Ratio & $100: 1$ \\
Electric Motor Rpm & 1400 \\
Minimum Power of Electric Motor & $9 \mathrm{~kW}^{*}$ \\
\hline
\end{tabular}

\section{References}

[1] Dave, Hansel. "Abrasive Blasting Systems". Clemco Industry Corp., Burlingame, Calif.

[2] Maintenance Data, PT. United Tractors Pandu Engineering, 2019.

[3] Lihua, Zhao and Yin Lin (2011)., "Typical Failure Analysis and Processing of Belt Conveyor", School of Mechanical Engineering, Northeast Dianli University: Procedia Engineering 26, pp. $942-946$.

[4] Anathet al. (2013)., "Research Paper about Design and Selecting the Proper Conveyor Belt", International Journal of Advance Engineering Technology, E-ISSN 0976-394.

[5] Bolat, B and Bogoclu, M (2012)., "Increasing of Screw Conveyor Capacity", Journal of Trends in the Development of Machinery and Associated Technology, vol. 16, Yildiz Technical University, Faculty of Mechanical Engineering.

[6] Roulunds Handbook., "Rubber Conveyor Belts". Roulounds Fabriker. pp. 5, internet:www.roulunds.com.

[7] Fenner Dunlop (2009)., "Conveyor Handbook", Conveyor Belting Australia. pp 1-70.

[8] Daniyan I.A et al. (2014)., "Design of Material Handling Equipment: Belt Conveyor Limestone Using 3 Roll Idlers", Journal of Advancement in Engineering and Technology, Department of Mechanical \& Mechatronics Engineering Afe Babalola University.

[9] R.S. Khurmi and J.K. Gupta, "A Textbook of Machine Design (S.I. Units)”, 1^st Multi-colour ed. New Delhi: Eurasia Publishing House PVT. LTD, 2005, pp. 115.

[10] CKIT, "Fabric Conveyor Belt: Minimum Recommended Pulley Diameters". Internet: https://www.ckit.co.za/secure/conveyor/troughed/belting/fabric_table4.html [Dec. 6, 2019].

[11] Transroll Catalogue, "Roller and Garland Station For Belt Conveyors". Internet: https://www.transroll.cz/obrazky-soubory/produktovy-katalog-en-0ddd0.pdf?redir [Dec. 7, 2019]. 